\title{
УКРАЇНСЬКО-БІЛОРУСЬКО-ПОЛЬСЬКЕ ПОРУБІЖЖЯ В АСОЦІАТИВНОМУ СЛОВНИКУ ВЛАСНИХ ОСОБОВИХ ІМЕН (ВСТУПНІ СПОСТЕРЕЖЕННЯ)
}

\author{
Григорій Аркушин \\ Волинський національний університет імені Лесі Українки \\ ORCID: 0000-0002-0698-6347
}

\begin{abstract}
Анотація. Проаналізовано Асоиіативний словник власних особових імен О. Нестерчук, у якому подані студентські реакції на православні найменування людей (Ігнась, Макарусь, Міхал, Ясь > білорус; Владзьо, Свгеніуш, Штефан > поляк; Антон, Вадімчик, Владік, Гомелько, Павлуша, Славусь, Качіріна, Клавуня, Ліда, Голена, Голька > Білорусь; Адам, Геньо, Лях, Міхал, Павел, Ростислав, Штефан, Тиміш, Яник, Каціріна, Лідка, Мар'я, Алєксандра, Альона, Ольга, Зоська > Польща). Установлено, що ці реакції дають відповіді на питання не тільки про власні особові імена, а й всебічно характеризують індивідуума, зокрема вказують, як студенти знають історію, що читають, яким фільмам надають перевагу, хто для них кумир, якою музикою захоплюються, яке їхнє ставлення до церкви та релігії, без яких росіїзмів ще не можуть обійтися у своєму мовленні та ін. I крім цього, знаходимо багато фактів про українсько-білорусько-польське суміжжя.
\end{abstract}

Ключові слова: асоціації, слово-стимул, реакція, українсько-білоруське порубіжжя, українсько-польське порубіжжя

Головна тема наукових досліджень нашого славного ювіляра - професора габілітованого Фелікса Чижевського - це польсько-східнослов'янські, насамперед польсько-українські, мовні зв'язки. Про це свідчать такі здобутки, якими, зокрема, ми в Україні найчастіше користуємося: Atlas gwar polskich i ukraińskich okolic Włodawy (1986), Fonetyka ifonologia gwar polskich i ukraińskich potudniowo-wschodniego Podlasia (1994), Polskie i ukrainskie teksty gwarowe ze wschodniej Lubelszczyzny (співавтор Стефан Вархол, 1998), Antroponimia pogranicza polsko-wschodniostowiańskiego w świetle Inikrypcji nagrobnych. Część 1. Stownik nazwisk (2013) та ін. Наш ювіляр член багатьох редколегій та редактор видань Język $i$ kultura na pograniczu polsko-ukraińsko-białoruskim (2001), Z dialektologii stowiańskiej (2002), Z zagadnień językoznawstwa stowiańskiego (2011), Cmentarze po obu stronach Bugu (2014), Centrum a peryferie w opisach językoznawczych (2016) та багатьох інших. Професор переконаний, що державні чи адмі- 
ністративні кордони не стають відрубною межею між мовами чи діалектами навіть однієї і тієї ж мови.

А іноді трапляється так, що якусь цікаву нам тему віднаходимо і там, де, на перший погляд, iii і не могло бути. Наприклад, що може бути спільного між Асоиіативним словником власних особових імен ${ }^{1}$ Оксани Нестерчук і польсько-східнослов'янськими зв'язками? Але це тільки на перший погляд...

Отож, спершу більш докладно про це лексикографічне видання.

Асоиіативний словник власних особових імен Оксани Нестерчук це, наскільки знаємо, друге в Україні видання такого типу, першим був Словник асоиіативних норм української мови ${ }^{2}$ Ніни Бутенко, який став бібліографічною рідкістю (зауважимо, що вже видані норми словесних асоціацій багатьох мов - англійської, російської, польської, білоруської, казахської та ін.).

У таких працях досліджують зв'язок між психічними явищами, коли запропоноване слово-стимул викликає певну реакцію на нього. Як зазначено в одинадцятитомному Словнику української мови, ,асоціація - зв'язок між окремими нервово-психічними актами - уявленнями, думками, почуттями, внаслідок якого одне уявлення, почуття і т.ін. викликає інше”. Асоціативне поле стимулу зростає „завширшки” i ,завдовжки” разом із віком людини і залежить від багатьох чинників: життєвого досвіду, освіти, місця проживання, кола родичів і друзів, оточення, громадянства, політичного устрою держави і т.д.

У словнику Н. Бутенко львівським студентам були запропоновані, наприклад, такі апелятиви-стимули: дитина, гора, дорога, горілка, річка, релігія, сон та ін. О. Нестерчук запропонувала луцьким студентам православні власні особові імена як стимули. Ці власні найменування живуть тільки в людському середовищі (виняток - клички тварин), але зі смертю індивіда не зникають, а продовжують функціонувати в нашій пам'яті, збуджуючи позитивні чи негативні спогади. Звичайно, довго живуть ті імена-спомини, що належали „позитивним” особам, але за тривалістю пам'ятування їх „обганяють” найменування „негативних” осіб, бо така людська непроще́нна і не християнська пам'ять, що за побутовими клопотами і дрібницями часто забуваємо слова молитви - I прости нам наші провини, як і ми прощаємо винуватиям нашим.

Для кожного історичного періоду свої асоціації, що „збуджують” пам'ять, а потім довго „живуть” у кожного з нас, і від них відмовитися годі; пор. асоціації на стимул Володимир > Володимир Великий, князь,

О. Нестерчук, Асоиіативний словник власних особових імен, Луцьк 2019.

Н. Бутенко, Словник асоиіативних норм української мови, Львів 1979.

Словник української мови, т. 1, ред. І. Білодід, Київ 1970, с. 67. 
хреститель Русі, Сапіга, Винниченко, Ленін, Височький, Кличко, Лис, Зеленський і т.д.

В Асоиіативному словнику власних особових імен представлено повні православні найменування - 82 чоловічих та 54 жіночих, разом із варіантами усіх 946 імен. Таку кількість було запропоновано студентам луцьких вишів під час вільного асоціативного експерименту, щоб визначити їхні реакції на імена-стимули. При цьому була поставлена умова: фіксувати асоціації лише ті, що виникали у перші секунди, не вигадуючи і „не вимучуючи” відповіді: „Лише перша асоціація на запропонований стимул $\epsilon$ найбільш надійною". Так за допомогою анкет (іх опрацьовано понад пів тисячі) отримано відповіді від респондентів віком 16-25 років, народжених переважно у Волинській, Рівненській та Львівській областях.

Крім повних офіційних імен стимулами ставали і їхні варіанти не лише вживані в літературній мові, а й ті, що широко знані в західнополіських та волинських говірках, насамперед запозичені з російської та польської мов, пор.: Михайло - Михаӥл, Михалко, Михайлик, Михлик, Михась, Мисько, Мишко, Міша, Мішка, Мішута, Міхал, Мехаль та ін.

Анкети дають відповіді на багато питань, що не стосуються найменування людей, зокрема на такі: як студенти знають історію, що читають, яким фільмам надають перевагу, хто для них кумир, якою музикою захоплюються, їхнє ставлення до церкви та релігії, без яких росіїзмів ще не можуть обійтися у своєму мовленні і т.ін. Як сказано у передмові, „пропонований словник - це маленьке віконечко у внутрішній світ нашого луцького студентства".

Оскільки північно-західна Україна межує на півночі з Республікою Білорусь, а на заході з Республікою Польща, утворюючи трикутне українсько-білорусько-польське суміжжя, то на основі асоціацій особових імен можна виявити, наскільки це порубіжжя відобразилось у студентській пам'яті.

\section{РЕСПУБЛІКА БІЛОРУСЬ}

власне ім'я (стимул) > прізвище (реакція)

Єдиний приклад: Кіндрат > білоруський поет, Кропива (відомий білоруський письменник Кандрат Крапіва); пор. приклад без антропоніма - Зоська > білоруська поетеса (очевидно, мається на увазі письменниця Зоська Верас, справжнє ім'я - Людвіка Антонаўна Савіцкая-Войцік).

4 А. Супрун, Bступ, [в:] Н. Бутенко, Словник асоиіативних норм украӥнської мови, Львів 1979, с. 4.

5 О. Нестерчук, цит. праця, с. 10. 


\section{власне ім'я (стимул) > етнонім (реакція)}

На думку студентів, вісім чоловічих імен мають білоруське „забарвлення": Адамчик, Артем, Ігнась, Кіріл, Кіндрат, Макарусь, Міхал, Ясь > білорус; ще одне ім'я з уточненням: Аліксандр > друг з Білорусї̈; і чотири жіночі імені - Качіріна, Олеся, Волька, Свєтлана - викликали реакцію білоруска (від імені Качіріна 6 реакцій); пор. ще Качіріна > білоруська дівчина (3 реакціі).

$$
\text { власне ім'я (стимул) > країна (реакція) }
$$

Одинадцять імен для студентів асоціюються з назвою сусідньої країни: Антон, Вадімчик, Владік, Гомелько, Павлуша, Славусь, Качіріна, Клавуня, Ліда, Голена, Голька > Білорусь || Білорусія. Безперечно, лише самі студенти могли б пояснити свої реакції, бо незрозуміло, що „білоруського" відчули у варіанті Гомелько; однак трапляються і цікаві уточнення, пор.: Григір > так кажуть білоруси. Варіанти Владік, Павлуша надзвичайно поширені в Білорусі, тому вже майже втратили „російськість" і сприймаються своїми, тобто білоруськими (російська і білоруська - державні мови Республіки Білорусь), а в імені Каціріна визначальним залишилося білоруське цекання.

$$
\text { власне ім'я (стимул) > ойконім (реакція) }
$$

Серед реакцій власних назв поселень виявлено чотири найменування білоруських міст: Григорчик > Мінськ; Гомелько > Гомель (дві реакціі); Ліда > місто в Білорусї̈; Міла і Ніна > Брест, Христя > з Бреста. Найзрозуміліша реакція на стимули Ліда (омонімічна назва білоруського міста Гродненської області) та Гомелько (звукова подібність 3 назвою Гомель).

\section{РЕСПУБЛІКА ПОЛЬЩА}

власне ім'я (стимул) > власне ім'я (реакція)

Звичайні чотири українські імені викликають реакції польських імен, при цьому їхній зв'язок абсолютно незрозумілий: Віктор > Фелікс, Максік > Марик, Назар > Франик, Прусьочка > Ядвіга.

Варіанти Вадик, Валик, Лодік, Владзьо, Гарась, Гарасько, Свгеніуш, Яша, Сндрик, Зеник, Ян викликали реакцію польське ім'я. Для дванадцяти варіантів-стимулів Володимирко, Володько, Генька, Регор, Міхал, Овксентій, Павел, Сімеон, Штефан, Харитін, Волена, Марися студенти подали реакцію просто польське.

Серед перерахованих найменувань нічого „польського” немає у варіантах Вадик, Валик, Володимирко, Володько, Гарасько, Овксентій, Яиа, Харитін, Волена, у протилежність іменам Владзьо, Свгеніуш, Штефан, Марися, пор. уточнення Владзьо > ім'я Володя в Польщі. Засвідчена суб- 
ституція польських суфіксів -ек на -ик $\|$-ік: Зеник, Лодік (<Влодек), Марик, Франик.

власне ім'я (стимул) > антропонім (реакція)

Певні зв'язки знаходимо між іменами, уживаними і в Україні, та прізвищами відомих польських письменників і вчених: Aдам > Miųкевич, Адамчик > Міцкевич (пор. ще таку реакцію: Адам > польська поезія), Лсра > Лер-Сплавінський || Тадеуш Лер-Сплавінський (мовознавець-славіст Tadeusz Lehr-Spławiński), Олька > Квятковська (можливо, мають на увазі молоду художницю українсько-польського походження Хелену Квятковську), Ян > Собоський (очевидно, це польський король Jan III Sobieski), Ігнат > польський вчений (незрозуміло, кого конкретно мають на увазі, бо з іменем Ignacy засвідчено багато польських учених, письменників і політичних діячів); пор. ще таку асоціацію: Станіслав $>$ П’ $є x a$ (внук теперішньої російської співачки, уродженки Польщі), так само Cmac \| Cmacb > П'єха; крім цього, російське ім'я Надєжда викликало асоціацію пісня Анни Герман (надєжда апелятив, укр. надія). Іноді „Польськість” виявляють і неофіційні найменування: Павел > Полячук (прізвисько).

Зрідка студенти не вказують антропоніми, а зазначають лише титул: Владіслав > король Польщі, Ян > польський король, не конкретизуючи, про кого саме йдеться.

власне ім'я (стимул) > ойконім (реакція)

Єдиний приклад - Варка > місто в Польщзі (Warka).

власне ім'я (стимул) > назва країни (реакція)

Двадцять три імені в уявленні студентів викликали реакцію Польща: Адам, Ванько, Валерій, Вітя, Владіслав, Свген, Геньо, Лях (як західнополіський варіант імені Ілля), Міхал, Олег || Алег, Павел, Ростислав, Стьопа, Штефан, Тиміш, Яник, Каціріна, Лідка, Мар'я, Алєксандра, Альона, Ольга, Зоська. Без тлумачення самих інформаторів незрозуміло, чому варіанти імен Алег, Ванько, Валерій, Вітя, Стьопа, Лідка та ін. асоціюються з Польщею.

власне ім'я (стимул) > етнонім (реакція)

Реакція поляк у луцьких студентів виникала на тридцять шість стимулів чоловічих власних особових імен та їхніх варіантів: Адамцььо, Ядам, Богданчик, Володько, Владзьо, Ладимір, Ігнат, Гнатко, Митька, Свгеніуш, Женя, Зінько, Зеник, Лях (варіант імені Ілля), Йосипко, Кирилко, Льониььо, Льоньдзя, Максимиььо, Марчик, Міхал, Олько, Павелко, Пьотр, Славчик, Стах, Сірошка, Штефан, Тиміш, Хведор, Ян, Яник, Янчик, Ясь, Яųь; пор. ще такі уточнення: Лукаш > знайомий поляк, Лях (варіант імені Ілля) > польський лемко.

Реакція лях як зневажлива назва виникла на імена-стимули Свгеніуш, Іллящ, Лях (західнополіський варіант імені Ілля), Люк ('те ж саме’). 
Реакція полячка виникала на дев'ять стимулів жіночих імен та їхніх варіантів: Галіна, Дануся, Домка, Домия, Зоська, Качіріна, Кася, Тома; пор. уточнення: Кася > викладач з Польщі; Каська > знайома полячка. Сім імен-стимулів дали реакцію полька: Данка, Зося, Каціріна, Мария, Олько, Олька, Танюша. Інші реакції, що виявляють „польськість”: Гандзя > забужанка, тобто переселенка з-за Бугу в Україну; Христєта > кубіта; Мисько > холера ясна; Льоньдзя > польська страва (?); Яник > «Намі пані у Варшаві» (герой телесеріалу).

Зауважимо також, що авторка не проводила опитування серед студентів-полоністів, однак реакції свідчать, що знання про Польщу у луцьких студентів більші, ніж про Білорусію, незважаючи на те, що їхати в Білорусію простіше: тут ніколи не запроваджували візи, потрібен лише внутрішній паспорт, а на митниці практично відсутні черги. Але знань про Польщу в луцьких студентів більше, чому сприяють частіші поїздки родичів і їх самих „на закупи” та на „трускавки, черешні, капусту” i т.д., а дехто із знайомих вчиться у польських вишах, там уже мають друзів. Одні і ті ж імена-стимули для одних студентів виявляють „білоруськість”, для інших - „польськість”, пор.: Аліксандр $\|$ Алєксандра, Ясь, Зоська, Качіріна.

Ось таке різноманітне українсько-білорусько-польське суміжжя в асоціаціях луцького студентства.

\section{БІБЛІОГРАФІЯ}

Butenko Nìna. 1979. Slovnik asociativnih norm ukrä̈ns'koï movi. L'vìv: Vidavnictvo pri L'vìvs'komu deržavnomu unìversitetì vidavničogo ob êdnannâ «Viŝa škola». [Бутенко Ніна. 1979. Словник асоиіативних норм украӥнської мови. Львів: Видавництво при Львівському державному університеті видавничого об’єднання «Вища школа»].

Nesterčuk Oksana. 2019. Asociativnij slovnik vlasnih osobovih ìmen. Luc'k: PP İVANÛK V.P. [Нестерчук Оксана. 2019. Асоиіативний словник власних особових імен. Луцьк: ПП Іванюк В.П.].

Slovnik ukraïns'koï movi. 1970-1980. T. 1-11. Kï̈v:Naukova dumka]. [Словник української мови. 1970-1980. Т. 1-11. Київ: Наукова думка].

Suprun Adam. 1979. Vstup. V: Butenko Nìna. Slovnik asociativnih norm ukraïns'kö̈ movi. L'vìv: Vidavnictvo pri L'vìvs'komu deržavnomu unìversitetì vidavničogo ob êdnannâ «Viŝa škola»: 3-12. [Супрун Адам. Встуn. В: Бутенко Ніна. Словник асоиіативних норм украӥнської мови. Львів: Видавництво при Львівському державному університеті видавничого об’єднання «Вища школа»: 3-12]. 


\title{
UKRAINIAN-BELARUSIAN-POLISH BORDER IN THE ASSOCIATIVE DICTIONARY OF PERSONAL FIRST NAMES
}

Summary. The Associative dictionary of personal first names by O. Nesterchuk, which presents student reactions to Orthodox names of people, was analyzed (Ігнась, Макарусь, Міхал, Ясь > Belorussian; Владзьо, Євгеніуш, Штефан > Pole; Антон, Вадімчик, Владік, Гомелько, Павлуша, Славусь, Качіріна, Клавуня, Ліда, Голена, Голька > Веlarus; Адам, Геньо, Лях, Міхал, Павел, Ростислав, Штефан, Тиміш, Яник, Качіріна, Лідка, Мар'я, Алєксандра, Альона, Ольга, Зоська > Poland). It is established that these reactions answer questions not only about their own personal names, but also comprehensively characterize individuals, in particular, indicate how students know the story, read, what movies they prefer, who their idol is, what music they admire, what their attitude to the church and religion, without which Russianisms they cannot yet dispense with their speech, etc. And besides that, we find many facts about the Ukrainian-Belarusian-Polish contiguity.

Key words: associations, word-stimulus, reaction, Ukrainian-Belarusian border, Ukrainian-Polish border

\author{
POGRANICZE UKRAIŃSKO-BIAŁORUSKO-POLSKIE \\ W SLOWNIKU ASOCJACYJNYM WEASNYCH IMION OSOBOWYCH \\ (UWAGI WSTĘPNE)
}

Streszczenie. W artykule przeanalizowano Stownik asocjacyjny własnych imion osobowych O. Nesterczuk, w którym opisane zostały reakcje studentów na prawosławne nazwy osobowe (Ihnas', Makarus', Michat, Jas'> Białorusin; Władzio, Jewheniusz, Sztefan >Polak; Anton, Wadzimczyk, Władik, Homelko, Pawłusza, Sławus', Kacirina, Kławunia, Lida, Hołena, Holka > Białoruś; Adam, Genio, Lach, Michat, Paweł, Rostysław, Sztefan, Tumisz, Janyk, Kacirina, Lidka, Maria, Aleksandra, Alona, Olha, Zośka > Polska). Stwierdzono, że reakcje te dają odpowiedź nie tylko na pytanie o własne imiona osobowe, lecz także charakteryzują jednostkę na wielu płaszczyznach, w szczególności zaś wskazują na stopień znajomości historii przez studentów, na to, co czytają, jakie filmy preferują, kogo uważają za idola, jaką muzyką się pasjonują, jaki jest ich stosunek do cerkwi i religii, jakich rusycyzmów nie są w stanie uniknąć podczas mówienia itd. Ponadto dostarczają informacji o wielu faktach istniejących na pograniczu ukraińsko-białorusko-polskim.

Słowa klucze: skojarzenia, słowo-bodziec, reakcja, pogranicze ukraińsko-białoruskie, pogranicze ukraińsko-polskie 
